\title{
PEMANFAATAN TANAMAN DAUN GATAL (LAPORTEA DECUMANA) SEBAGAI OBAT ANTI CAPEK
}

\author{
UTILIZATION OF STINGGING NETTLE (LAPORTEA DECUMANA) \\ AS PAIN RELIEF
}

\author{
${ }^{1)}$ Eva Susanty Simaremare, ${ }^{2)}$ Rani Dewi Pratiwi, ${ }^{3)}$ Rusnaeni, ${ }^{4)}$ Elsye Gunawan, ${ }^{5}$ Septriyanto \\ Dirgantara \\ Program Studi Farmasi-Jurusan Farmasi FMIPA Universitas Cenderawasih \\ Jln. Kampwolker Jayapura Papua \\ email: eva_smare@yahoo.com
}

\begin{abstract}
ABSTRAK
Kampung WulukubunArso XIV, Distrik Skanto Kabupaten Kerombanyak ditumbuhi daun gatal yang bermanfaat sebagai obat tradisional sebagai antinyeri, mengurangi rasa capek, dan mengurangi pegal-pegal. Daun gatal banyak terdapat di kampung tapi sering sekali hanya dibiarkan kering, layu, mati, bahkan dibuang. Padahal nilai dari daun ini sangat besar jika dikembangkan tidak hanya lembaran daun gatal tetapi sebagai produk farmasi. Tujuan dari kegiatan ini adalah melakukan sosialisasi dan membuat sediaan topikal salep daun gatal di kampung Wulukubun Arso XIV Kabupaten Keerom Papua. Kegiatan ini dilaksanakan dengan melakukan persiapan di kampus/ administrasi, menjalin kerjasama dengan mitra, instansi terkait, kegiatan hari H di kampung, evaluasi, laporan, dan publikasi. Hasil yang diperoleh dari kegiatan ini adalah 7,4\% peserta pernah mengikuti kegiatan yang sama. Sebanyak 88,9\% peserta memperoleh manfaat dari kegiatan ini dan 70,4\% berkomitmen akan membantu orang lain dalam menyebarluaskan informasi penting yang mereka dapat pada waktu kegiatan ini.
\end{abstract}

Kata kunci : Daun Gatal, Simplisia, Salep

\begin{abstract}
Wulukubun Arso XIV, District Skanto Kerom regency is overgrown with stingging nettle leaves that are useful as traditional medicine as pain relief, reduce fatigue, and reduce stiffness. Stingging nettle leaves are found in the village but they are only allowed to dry, wilted, dead, even thrown away. On the other hand, the value of this leaf is higher if they are developed as pharmaceutical products. The purpose of this activity was to conduct socialization and make an ointment of itchy leaf in WulukubunArso XIV village, Keerom Papua Regency. This activity was carried out by preparing on campus/administration, cooperating with partners, related agencies, $H$ day activities in the village, evaluations, reports, and publications. The results showed $7.4 \%$ of participants have followed the same activity. As many as $88.9 \%$ of participants get new information from this activity and $70.4 \%$ committed to assist others in disseminating the information from this activity
\end{abstract}

Keywords: Stinging Nettle Leaf, Simplicia, Ointment

Submited : 28 Juli $2018 \quad$ Revision : 11 Desember 2018 Accepted : 6 Januri 2019

\section{PENDAHULUAN}

Kampung Walukubun, Arso XIV berada di Distrik Skanto Kabupaten Kerom yang berjarak kira-kira 54,3 km dari Uncen yang ditempuh kurang lebih 2 jam. Hutan di distrik ini banyak ditumbuhi oleh tanaman daun gatal (Laportea decumana) yang sebagian masyarakat digunakan sebagai tanaman obat antinyeri topikal. Akan tetapi di sisi lain banyak juga masyarakat pendatang tidak mengenal tanaman ini, sehingga tanaman ini tidak 
dipelihara atau dirawat dengan baik oleh masyarakat karena masyarakat tidak memahami dengan baik penggunaan tanaman ini secara etnofarmakologi.

Daun gatal (L. decumana) merupakan tanaman dimana bentuk daun bergerigi dan memiliki bulu-bulu halus di sepanjang daun dan batang (Gambar 1). Tanaman daun gatal dengan spesies yang berbeda di antaranya Laportea aestuan (Okereke and Elekwa, 2014), L. ovafolia (Nzeugeumet al., 2015), L. interrupta (Njina et al., 2006; Tchinda et al., 2017), L. canadiensis (Reauma, 2010; Tuberville et al., 2007), juga dimanfaatkan di negaranegara lain seperti di Nigeria, Kamerun, Filipina (Oloyede and Oyelola, 2013; Oloyede, 2016), Bangladesh, Sri Langka, India (Khan et al., 2007), dan beberapa negara di Eropa.

Tumbuhan ini banyak dimanfaatkan oleh masyarakat secara etnofarmakologi termasuk di distrik Depapre sebagai obat antinyeri/ analgesik secara tradisional. Khususnya masyarakat Arso XIV dan kota-kota lain di menggunakan tanaman ini untuk mengatasi keluhan kesehatan sebagai antinyeri seperti rasa sakit, kaku/ pegal, sakit perut, dan capek secara efektif (Holledkk, 2015; Simaremare dkk, 2014; Simaremare, 2014).Tanaman ini sangat efektif karena memiliki senjata berupa rambut atau bulubulu kaku (trikoma) yaitu asam format yang dipercayai secara turun temurun jika ditempel pada bagian tubuh yang sakit, pegal, kaku, nyeri akan segera sembuh. Ketika trikoma dioleskan dalam tubuh, maka asam format akan keluar dari trikoma dengan proses enzimatis. Asam format akan memperlebar pori-pori darah sehingga darah lancaar mengalir dan mekanisme ini lah yang mengurangi rasa nyeri dan capek pada badan atau otot (Simaremare dkk, 2014; Simaremare dkk, 2015).

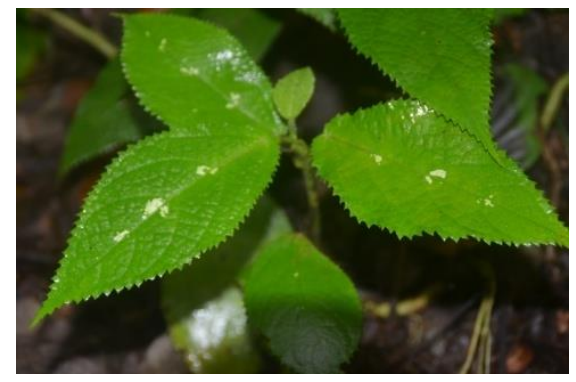

Gambar 1. Daun gatal

Beberapa masyarakat sangat percaya dan mempraktekkan pemakaian daun gatal untuk kesembuhan. Daun gatal tipe daun lebar digunakan dengan memukul mukul daun gatal pada bagian yang nyeri dengan tingkat kesakitan yang tinggi sedangkan daun gatal tipe daun kecil hanya diusapusapkan pada bagian yang capek (Simaremare dkk, 2017). Daun ini merupakan tanaman endemik Papua yang sudah digunakan secara tradisional secara turun-temurun dan sangat bermanfaat sekali untuk masyarakat di Papua khususnya masyarakat Arso.

Daun gatal dijual di pasar tradisional rakyat dengan mengambil lembaran daun gatal dan menyusunnya (sekitar 10 lembar) menjadi ikatan-ikatan kecil yang biasanya dijual seharga sepuluh ribu rupiah (Simaremare dkk, 2014). Para penjual daun gatal yang ada di pasar tradisional seperti pasar Youtefa berasal dari masyarakat Genyem (45,5 km dari kota Abepura, salah satu pusat aktivitas terebsar di Jayapura). Dari hasil survei di lapangan, para penjual hanya membawa 10-20 ikat daun gatal untuk dijajakan di pasar. Untuk mempertahankan kasiatnya perlu dibuat daun gatal kering supaya tidak busuk dan dapat bertahan lama (bulanan) yaitu dalam bentuk simplisia.

\section{METODE}

Kegiatan ini diikuti 83 orang masyarakat tetapi yang mengisi kuisoner hanya 27 orang (sampel yang mewakili). 
Peserta yang mengikuti kegiatan ini dapat diklasifikasikan dari jenis kelamin, usia, pekerjaan, pendidikan, dan umur. Peserta yakni ada 19 orang perempuan dan 8 orang laki-laki dimana dari peserta perempuan dan laki-laki didominasi sebagai petani. Rentang usia peserta yang mengikuti pengabdian ini adalah usia 1465 tahun seperti pada Tabel 1 .

Tabel 1. Data peserta dalam kegiatan pengabdian pada masyarakat Arso XIV

\begin{tabular}{lrl}
\multicolumn{1}{c}{ XIV } & Jumlah \\
\hline Jenis kelamin & 8 & \\
\hline Laki-laki & 19 & \\
Perempuan &
\end{tabular}

Pendekatan dalam melakukan pengabdian kepada masyarakat Arsodilakukan melalui komunikasi selanjutnya workshop dan sosialisasi serta pelatihan dilakukan. Kegiatan ini berupa sosialisasi dan penjelasan penerapan teknologi Farmasi bahan alam dalam meningkatkan nilai jual dari daun gatal. Pembuatan ini akan dibimbing oleh tim pelaksana dari staf Farmasi UNCEN dengan melibatkan mahasiswa dan masyarakat setempat.

Metode dan tahapan dalam penerapan iptek $\%$ $\begin{array}{lll} & \text { Penelitian yang telah dikembangkan } \\ \text { Jenis kelamin } & \text { Jumlah telah menghasilkan produk simplisia dan }\end{array}$

Papua $\quad 8 \quad$ sale $3 \%$ daun gatal. Hasil penelitian ini

Maluku dan kepulauan 2 diteragrkan dalam program pengabdian

Sulawesi 5 kepaxda masyarakat di Arso.Metode yang

Jawa 10 dilakk 10 pada produk ini dibuat dengan

NTT mengambil daun dari pohonnya kemudian

$\begin{array}{llll}\text { NTT } & 2 & \text { dikeringkan di bawah sinar matahari. Daun } \\ \text { Usia } & \text { Jumlah gatal dihaluskan dan dibuat menjadi }\end{array}$

$\begin{array}{lll}10-20 \text { tahun } & 8 & \text { satal dihaluskan dan dibuat menjadi }\end{array}$

21-30 tahun $\quad 2 \mu \mathrm{m}$ dimasukkan dalam kemasan dan

31-40 5 dipagking dengan baik. Setelah simplisia

41-50 10 diperoleh kemudian diformulasi dengan

bahan-bahan yang lain untuk menghasilkan

51-60 $1 \quad$ prodtik daun gatal.

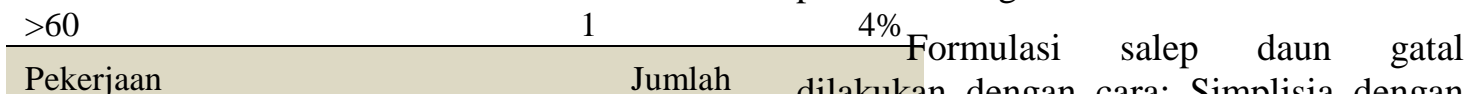

$\begin{array}{llll} & \text { Jumlah dilakukan dengan cara: Simplisia dengan }\end{array}$

Pelajar 8 ukıfelra pori 175 dibuat salep basis larut air.

PNS 7

Swasta 3

Petani 9

Tabel 1menunjukkan bahwa daerah penduduk Arso didominasi dari penduduk pendatang lebih dari dua kali lipat dari penduduk asli. Daerah Arso memang banyak dihuni masyarakat transmigran karena perluasan daerah yang lebih banyak didominasi bekerja sebagai petani. Hasil pertanian Arso yang paling banyak yaitu sayur mayur, buah-buahan seperti jeruk, buah naga, semangka, dan lain-lain.
PE\&6\%4000 dileburkan terlebih dahulu sampaj mencair kemudian ditambahkan dengan PEG 400 dan metil paraben. Setelah tercampur dengan sempurna, simplisia daun gatal dimasukkan dan dilanjutkan dengan minyak gandapura(Simaremare $\mathrm{dkk}, \quad 2015$; Simaremare dkk, 2016).

\section{Evaluasi kegiatan}

Evaluasi kegiatan dilakukan dengan membuat instrumen berupa kuisoner. Setiap peserta akan dibagikan kuisoner dan diminta mengisi baik biodata, pemahaman atau pengetahuan tentang kegiatan yang dilakukan. Selanjutnya data disimpan dan 
dianalisis dan tingkat keberhasilan kegiatan dapat diukur. Evaluasi keberlanjutan program dilakukan pemantauan setelah kegiatan telah selesai dan masyarakat melakukan hasil kegiatan pengabdian ini.

\section{HASIL DAN PEMBAHASAN}

Masyarakat Arso XIV sudah mengenal banyak tanaman obat termasuk daun gatal (Tabel 2) sejak lama. Bahkan mereka menggunakan daun gatal ini setelah selesai bekerja di ladang atau baru pulang perjalan jauh. Dari data yang diperoleh, umumnya masyarakat yang menggunakan daun gatal sebagai obat tradisional adalah masyarakat Maluku dan Papua karena mereka sudah secara terun-temurun menggunakan daun ini (Heyne, 1987; Tualeka, 1986). Sedangkan masyarakat lain lebih mengetahui dan belum menggunakan sebagai swamedikasi.

Tabel 2. Persentase tingkat pengetahuan masyarakat Arso XIV tentang daun gatal

\begin{tabular}{llll}
\hline Jenis & Jumlah & \multicolumn{2}{l}{ Persentase } \\
\hline $\begin{array}{l}\text { Mengenal daun } \\
\text { gatal }\end{array}$ & Ya & 21 & $77,8 \%$ \\
\cline { 2 - 4 } & Tidak & 6 & $22,2 \%$ \\
\hline $\begin{array}{l}\text { Menggunakan } \\
\text { daun gatal }\end{array}$ & Ya & 23 & $85,2 \%$ \\
\hline $\begin{array}{l}\text { sebagai anti } \\
\text { pegal }\end{array}$ & Tidak & 4 & $14,8 \%$ \\
\hline
\end{tabular}

Kegiatan pengabdian ini mendapat apresiasi dari masyarakat karena kampung jarang didatangi sosialisasi seperti pada kegiatan ini (Tabel 3).
Tabel 3. Persentase kemanfaatan kegiatan pengabdian pada masyarakat Arso XIV

\begin{tabular}{lcc}
\hline $\begin{array}{c}\text { Kemanfaatan } \\
\text { kegiatan }\end{array}$ & Jumlah & Persentase \\
\hline Tidak bermanfaat & 0 & $0,0 \%$ \\
\hline Kurang bermanfaat & 0 & $0,0 \%$ \\
\hline Cukup bermanfaat & 3 & $11,1 \%$ \\
\hline Sangat bermanfaat & 24 & $88,9 \%$ \\
\hline
\end{tabular}

Pada kegiatan ini disampaikan tentang daun gatal, jenis-jenis daun gatal, senyawa apa yang dapat menghilangkan nyeri pada trikoma daun gatal. Data-data hasil-hasil penelitian daun gatal yang sudah pernah dilakukan juga membantu masyarakat mengerti bahwa daun gatal secara ilmu pengetahun sudah diteliti (Yasni dan Puro, 2012; Perdana dkk, 2016; Simaremare dkk, 2016). Selanjutnya disampaikan aktivitas farmakologis apa saja yang potensial dari daun gatal seperti aktivitas analgesik, antiinflmasi (Simaremare et al, 2018), dan antikoagulan (pengumpalan darah).

Pada pemakaiaan yang lebih sederhana, kegiatan ini menawarkan bahwa daun gatal dapat digunakan dalam bentuk kering (bukan daun asli yang masih basah). Hal ini mempermudah masyarakat untuk menyimpan tanpa kuatir akan busuk. Pembuatan simplisia dilakukan dengan cara mengeringkan daun di udara terbuka (kira-kira 7 hari) atau menjemur di bawah sinar matahari (3-4 hari). Setelah kering daun dihaluskan, dikemas, dan dapat digunakan kapan saja.

Pada kegiatan ini juga kami menyampaikan pembuatan pembuatan sedian topikal yaitu salep daun gatal. Pembuatan dilakukan dengan cara langsung mempraktekkan tahap demi tahap dari prosedur sehingga masyarakat mengerti cara melakukannya secara mandiri. Tetapi kendala yang muncul dari respon masyarakat adalah ketersediaan bahan baku yang masih awam buat masyarakat (sulit ditemukan) membuat mereka agak susah untuk memulai bisnis 
ini. Solusi yang ditawarkan adalah menjalin kerjasama dengan distributor yang sudah menjadi rekanan tim dan mulai mengurus ijin ke BPOM Jayapura.

Dari data analisis menjelaskan bahwa masyarakat sangat antusias dengan kegiatan ini. Hal ini dapat dilihat pada Gambar 1 bahwa masyarakat lebih dari 90\% sangat berkomitmen untuk berbagi informasi daun gatal dan pemanfaatannya terhadap orang lain di sekitar mereka.

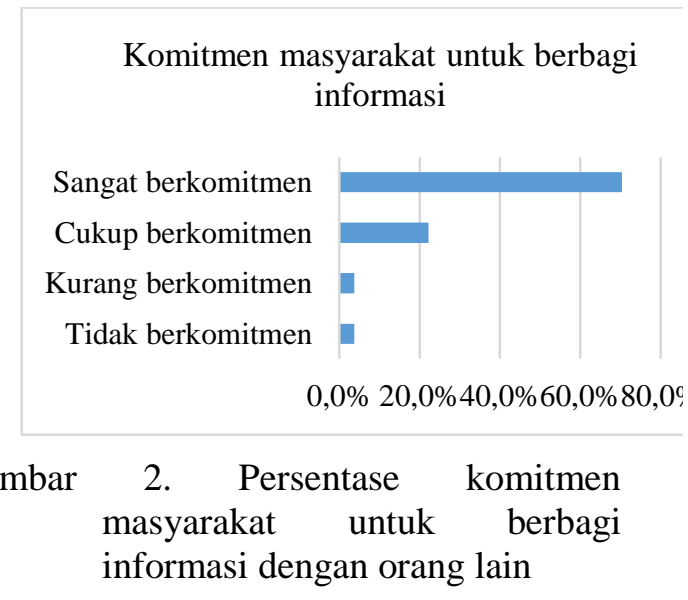

\section{SIMPULAN}

$7,4 \%$ peserta pernah mengikuti kegiatan yang sama. Sebanyak $88,9 \%$ peserta memperoleh manfaat dari kegiatan ini dan $70,4 \%$ berkomitmen akan membantu orang lain dalam menyebarluaskan informasi penting yang mereka dapat pada waktu kegiatan ini.

\section{UCAPAN TERIMA KASIH}

Ucapan terima kasih disampaikan kepada PNBP Universitas Cenderawasih, Jayapura Papua yang telah mendanai kegiatan ini dalam bentuk Hibah Pengabdian BOPTN tahun 2018.

\section{DAFTAR PUSTAKA}

Heyne K. (1987). Tumbuhan Berguna Indonesia II. Jakarta. Badan Litbang Kehutanan.
Holle, E, E. S. Simaremare, I. M. Budi, Y.R. Yabansabra, dan E. Gunawan. (2015). Evaluasi, Uji Aktivitas, Dan Pengembangan Produk Salep Daun Gatal Papua Varietas Biak. Prosiding Seminar Nasional Biologi PBI ke-XXIII. Jayapura 8-9 September 2015.

Khan, A. M. A. B, M. Abdul, A. Al-Bari, S Hasan, M. A. Mosaddik, M. M. Rahman, M. E. Haque. (2007). Antipyretic activity of roots of Laportea crenulata Gaud in rabbit.Research Journal of Medicine and Medical Sciences, 2(2):58-61.

Njina S. N., R. S. Tagne, B.P. Telefo, F. N. Zambou, D. M. Yemele, F. T. Mbiapo. (2006). Anti-androgenic, anti-oestrogenic, and antioksidan activities of aqueous extract of Laportea ovalifolia on adult rats. Internasional Journal of Phytomedicine,8:257-266.

Nzeugeum K. W. M., M. O. L. Dongmo, L. L. Lienou, P. B. Telefo. (2015). Effect of Laportea ovalifolia (urticaceae) on monosodium glutamate induced obese rats. African Article of Integrated Health, 5(2):48-53.

Okereke, S. C., I. Elekwa. (2014). Studies the in vitro antioxidant activity of Laportea aestuans leaf extract. $J$ of Environmental Sci, Toxicology and Food Technology, 8(1):33-41.

Oloyede, G. K., M. S. Oyelola (2013). Chrysen-2-ol-derivate from West Indian wood nettle Laportea aestuans (L.) Chew inhibits oxidation and microbial growth in vitro. EXCLI Journal, 12:894-906.

Oloyede, G. K. (2016). Toxicity, antimicrobial and antioxidant activities of methyl salicylate 
dominated essential oils of Laportea aestuans (Gaud.). Arabian Journal of Chemistry, 9(1):840-5.

Perdana, B. Y., A. P.Putra, dan A. Primanisa. (2016). Uji Toksisitas Daun Jelatang ( Laportea sinuate Blume) terhadapa Larva Nyamuk Aedes aegipty. Universitas Andalas. Diakses 21 September 2018.

Reauma T. 2010. Urticaceae Nettle Family. Nature Manitoba. [Online] Available at

http://www.naturemanitoba.ca/sites/ default/files/StingingNettle.pdf. [Accessed 4 Desember 2018].

Simaremare, E. S., E. Gunawan, A. Ruban, M. T. Nainggolan, dan C. Yenusi. (2014). Formulasi dan evaluasi Salep daun gatal. Seminar Nasional Tanaman Obat Indonesia. Universitas Katolik. Widya Mandala. Surabaya.

Simaremare, E. S. (2014). Skrining Fitokimia Ekstrak Etanol Daun Gatal (Laportea decumana (Roxb.) Wedd). Pharmacy, 11(01): 98-107.

Simaremare, E.S., A Ruban, M. Nainggolan, C. Yenusi, G Wabiser, dan E. Gunawan. (2014). Pemanfaatan Daun Gatal (Laportea Decumana (Roxb.) Wedd.) Varietas Biak Sebagai Antinyeri. Proseding Seminar Nasional Biologi, 5(1). Hal: 190-195.

Simaremare, E. S., E. Holle, Y.R. Yabansabra, I.M. Budi., dan E. Gunawan. (2015). Analisis Perbandingan Efektifitas Antinyeri Salep Daun Gatal Dari Simplisia Laportea Aestuans ( $L$ ) Chew dan Laportea Decumana (Roxb) Wedd. Pharmacy, 12 (1):1-10.
Simaremare, E.S., Y. R. Yabansabra, E. Gunawan, A. Ruban. (2016). Uji Mutu Fisik Sediaan Salep Daun Gatal (Laportea decumana (Roxb.) Wedd.) Sebagai Kandidat Antinyeri. Galenika, 3(2): 55-60.

Simaremare, E. S., A. Ruban, dan D. Runtuboi. (2017). Aktivitas Antibakteri Ekstrak Etanol Daun Gatal (Laportea aestuans (L) Chew). Jurnal Biologi Papua, 9(1):1-7.

Simaremare, E. S., E. Holle, E. Gunawan, Y. R. Yabansabra, F. Octavia, and R. D. Pratiwi. (2018). Toxicity, Antioxidant, Analgesic, and Antiinflamantory of Ethanol Extract of Laportea aestuans (Linn.) Chew. Journal of Chemical and Pharmaceutical Research, 10(5):1623.

Tchinda, C. F., I. K. Voukeng, V. P. Beng, V. Kuete. (2017). Antibacterial activities of the methanol extract of Albizia adianthifolia, Alchornea laxiflora, Laportea ovaliafolia and three other Cameroonian plants against multi drug resistant gram negative bacteria. Saudi Journal of Biological Sciences, 24(4): 950-5.

Tualeka, S. (1986). Pemeriksaan Farmakognostik dan Usaha Skrining Komponen secara Kromatografi Lapis Tipis daun gatal (Laportea decumana (roxb.) Wedd) asal Maluku. Skripsi. Universitas Hasanuddin.

Tuberville, T. D., P. G. Dudley, A. J. Pollard. (2007). Responses of invertebrata herbivores to stinging tricomes of Urtica dioica and Laportea canadensis. Oikos, 5: 8388.

Yasni dan Puro. (2012). Kajian Aktivitas Antibakteri Daun Gatel (Laportea 
Eva SusantyS., Rani Dewi P, Rusnaeni, Elsye Gunawan, Septriyanto Dirgantara Pemanfaatan Tanaman Daun Gatal (Laportea Decumana) Sebagai Obat Anti Capek

decumana (Roxb.) Wedd.) dan Daun

Benalu Cengkeh. Skripsi. Institut Pertanian Bogor. 